\title{
POTENCY OF RHIZOSPHERE BACTERIA TO PROMOTE RICE GROWTH UNDER SALINE CONDITION
}

\author{
SRI WIDAWATI ${ }^{*}$ and I MADE SUDIANA \\ Research Center for Biology, Indonesian Institute of Sciences CSC-LIPI, Bogor 16911, Indonesia
}

Received: 8 July 2015/Accepted: 25 July 2016

\begin{abstract}
Saline soil is a common problem in coastal paddy field, especially in Indonesia. Salinity affects rice growth and the activities of soil functional microbes, including functional bacteria, which play roles in plant growth. Some of these microbes are associated with rice plants and are able to survive under saline condition. The presence of functional microbes is also important to improve soil quality. Nitrogen and phosphate are essential soil nutrients and is available in soil due to the activities of nitrogen-fixing bacteria and free-living plant-associated bacteria. The objective of the present study was to obtain nitrogen-fixing, phosphate solubilizing and Indole Acetic Acid (IAA)-producing bacteria that are able to survive and promote the growth of rice under saline conditions. From rice and peanut rhizosphere, Caphosphate (Ca-P) solubilizing and nitrogen-fixing bacteria were isolated separately using specific media. Then, the CaP solubilizing ability, phosphomonoesterase activity and IAA-producing ability were quantitatively examined. Based on the abilities, 20 strains were selected and identified as Burkholderia cepacia-complex, Burkholderia anthina, Burkbolderia cenocepacia, Bacillus cereus-complex (three strains), Achromobacter spanius, Azospirillum sp. (four strains), Azotobacter sp. (three strains), Rhizobium leguminosarum, Rhizobium sp. (two strains), and Pseudomonas sp. (three strains). The inoculation of several single strains or the mixture of the selected strains promoted the growth of rice under saline conditions. These inoculants could be potential as biofertilizer in saline paddy fields.
\end{abstract}

Keywords: Indole Acetic Acid production, phosphate solubilization, plant growth promoting bacteria, nitrogen fixation, rhizosphere, rice

\section{INTRODUCTION}

Most of the fertile paddy fields in Indonesia are located in coastal area and experiences soil salinization due to seawater intrusion (Djufry et al. 2011). Salinity affects not only the growth of rice (Oryza sativa Linn.), but also the activities of functional soil microbes, including bacteria, that play roles in mineralization of macro and microelements for plant growth (Balser et al. 2006). Some of these bacteria are associated with rice plants and are able to survive under saline condition. The activity of soil microbes is an important aspect of biogeochemical cycles of carbon, nitrogen, sulfur, phosphorus, etc. (Banig et al. 2008). The presence of functional microbes is also important to improve the quality of soil (Wijebandara et al. 2009). Nitrogen and phosphate are essential nutrients and are available in soil due to the activities of nitrogen-fixing bacteria and

\footnotetext{
* Corresponding author: widadomon@yahoo.com
}

free-living plant-associated bacteria (Steenhoudt \& Vanderleyden 2000). Several bacteria belonging to the genera Rbizobium, Azotobacter and Azospirillum are able to fix nitrogen and solubilize phosphate (Nosrati et al. 2014). Some members of these genera also produce plant growth promoting hormone such as Indole Acetic Acid (IAA), gibberellins and cytokinins (Bhattacharyya \& Jha 2012). Therefore, these genera are regarded as important components of biofertilizer (Rao 1994; Bhattacharjee \& Dey 2014). Introduction of growth promoting bacteria can increase nitrogen availability for plants and enhance crop productivity. However, very little information is available for the effect of salinity on bacteria that have beneficial functions, such as nitrogen fixation, phosphate solubilization and the production of plant growth hormone (Pliego et al. 2011; Lugtenberg et al. 2013; Nakbanpote et al. 2014). The purpose of this study is to obtain nitrogen-fixing, phosphate solubilizing and IAA producing bacteria that are able to survive and 
promote the growth of rice under saline conditions.

\section{MATERIALS AND METHODS}

\section{Bacterial Sources}

Bacterial sources were obtained from collected rhizosphere of rice (Oryza sativa) and peanut (Arachis hypogaea) cultivated in the research field of Cibinong Science Center, West Java Province, Indonesia. The physical and chemical properties of this research field indicated that the soil is infertile soil (Table 1).

\section{Isolation of Bacteria}

Phosphate solubilizing bacteria were screened following the method of Park et al. (2011). Halo zone formation around colonies after 7 daycultivation at $30{ }^{\circ} \mathrm{C}$ on Pikovskaya medium was used as an indicator of Ca-Phosphate (Ca-P) solubilization (Nguyen et al. 1992). Nitrogenfixing bacteria were isolated targeting the genera Rhizobium, Azopirillum and Azotobacter according to Mubarik et al. (2011) and Salamone et al. (2012) as well as Aquilanti and Clementi (2004), respectively.

\section{Determination of Ca-P Solubilization}

Ca-P solubilizing ability of the isolated strains was quantitatively determined according to Chen et al. (2006) by measuring orthophosphate in the culture fluid after 7 days of cultivation. Orthosphosphate determination was conducted according to Vassileva et al. (2000).

\section{Determination of Phosphatase Activity}

Extracellular phosphomonoesterase (PMEase) activity of the strains was determined following the method of Tabatabai and Bremner (1969) using p-nitrophenyl phosphate. The unit of the PMEase activity was defined as $\mu \mathrm{mol} /$ hof $\mathrm{p}$ nitrophenol released in $1 \mathrm{~mL}$ of extracellular enzyme solution that was fractioned from $1.0 \mathrm{~mL}$ of the culture fluid after 7 days of cultivation.

\section{Determination of IAA Production}

The IAA production of the strains was investigated after 7 days of cultivation, following the methods of Crozier et al. (1988) and Gravel et al. (2007).

\section{Selection and Identification of Bacteria}

Based on the Ca-P solubilization, PMEase activity and IAA production abilities, a total of 20 strains were selected from the above strains for rice growth assays. Identification of the 20 strains was performed following the method of Otsuka et al. (2008) based on the 16S rRNA gene sequence with 16S-9F (5GAGTTTGATCCTGGCTCAG-3) and 16S1510R (5-GGCTACCTTGTTACGA-3) primers.

\section{Rice Growth Assay at the Stage of Germination under Saline Condition}

One strain out of 10 taxonomic groups was selected and subjected to a root and shoot growth assay of rice at the stage of germination based on Zaller (2007) and Cerabolini et al. (2004). Briefly, ten seeds of three rice cultivars, INPARA-3, INPARI-13 and INPARA-6 were soaked in sterile water for 5 hours in their respective containers. These 10 rice seeds were then arranged based on their respective cultivars on top of filter paper which was put inside a Petridish $(20 \mathrm{~cm}$ in diameter). Fifteen milliliter of $4.0 \mathrm{~g} / \mathrm{L} \mathrm{NaCl}$ solution was poured onto the filter paper inside

Table 1 Physical and chemical properties of soils in the research field

\begin{tabular}{|c|c|c|c|c|c|c|c|c|c|c|c|}
\hline Parameter & $\begin{array}{c}\mathrm{P} \\
(\%)\end{array}$ & $\begin{array}{l}\mathrm{K} \\
(\%)\end{array}$ & $\begin{array}{c}\mathrm{C} \\
(\%)\end{array}$ & $\begin{array}{l}\mathrm{N} \\
(\%)\end{array}$ & $\begin{array}{l}\mathrm{C} / \mathrm{N} \\
\text { ratio }\end{array}$ & $\begin{array}{l}\mathrm{Ca} \\
(\%)\end{array}$ & $\begin{array}{c}\text { Exchangable } \\
\mathrm{Mg} \\
(\%)\end{array}$ & $\begin{array}{c}\text { Exchangable } \\
\mathrm{Na} \\
(\%)\end{array}$ & $\begin{array}{c}\text { Exchangable } \\
\text { Al dd } \\
(\%)\end{array}$ & $\begin{array}{l}\text { Soil } \\
\mathrm{pH}\end{array}$ & $\begin{array}{l}\text { Amount } \\
\text { of } \\
\text { bacteria } \\
\text { population }\end{array}$ \\
\hline Characteristic & 0.173 & 0.045 & 1.303 & 0.36 & 3.61 & 11.41 & 0.57 & 0.30 & 0.04 & 5.8 & $10^{4}-10^{5}$ \\
\hline $\begin{array}{l}\text { Determined } \\
\text { accoding to } \\
\text { Rowell (1994) }\end{array}$ & $\begin{array}{l}\text { Very } \\
\text { low }\end{array}$ & $\begin{array}{l}\text { Very } \\
\text { low }\end{array}$ & Low & Moderate & $\begin{array}{l}\text { Very } \\
\text { low }\end{array}$ & High & Low & Low & Low & Acid & Infertile \\
\hline
\end{tabular}


each Petridish, on which 10 rice seeds were lined up, followed by $1.0 \mathrm{~mL}$ of bacterial inoculant suspension containing $10^{\circ}$ cells $/ \mathrm{mL}$. Root and shoot lengths were measured at 7 days after germination. This experiment was set up using Complete Randomized Design with three replications.

\section{Rice Growth Assay at 45 Days after Planting under Saline and Non-Saline Conditions}

Ten strains out of 20 isolates tested on germination test were then subjected to rice growth assay for 45 days under saline condition with $0.4 \% \mathrm{NaCl}$. The number of cells for each treatment was adjusted to about $3.2 \times 10^{7}$. This value was selected based on the number of bacteria commonly found in paddy field soil. In a preliminary test (rice growth assay at the stage of germination), INPARI-13 and INPARA-6 could not grow well under the same saline condition. Therefore, only INPARA-3 was used in this assay. Four seeds of INPARA-3 were planted to experimental pots ( 0.5 gallon pots) containing sterile sands $(1.5 \mathrm{~kg})$ flooded with water(field capacity of sands $=24 \%$ or $360 \mathrm{~mL}$ ). Treatments applied were: 1 . Saline condition (adding $360 \mathrm{~mL}$ of $0.4 \% \mathrm{NaCl}(6 \mathrm{~g} \mathrm{NaCl})$ to the 0.5 gallon pots) and 2 . non-saline condition (without $0.4 \% \mathrm{NaCl}$ ). Into each pot, $5 \mathrm{~mL}$ of bacterial inoculant suspension was added. The result of experiment is shown in Table 5. After 7 days, the second inoculation with the same amount of bacterial suspension was conducted. The water level in pot was regulated by adding sterile water to compensate water decrease due to evaporation. The electrical conductivity (EC) value of the assay media under saline condition was kept at $7.5 \mathrm{mS} / \mathrm{cm}$. At 45 days after planting the growth of rice was evaluated. This experiment was set as complete randomized design performed with three replications.

\section{RESULTS AND DISCUSSION}

\section{Composition of the Strains}

The selected 20 strains, originated from the rhizosphere of rice and peanut, belonged to the genera Burkholderia, Bacillus, Achromobacter, Pseudomonas, Azospirillum, Rhizobium and Azotobacter (Table 2). The selected strains were originated from non-saline soil. The reason for the selection was to compare the physiological characteristics of microbes isolated from saline and non-saline soil. The result of this study showed that the functional microbes for

Table 2 List of bacteria isolated from rice and peanut rhizosphere

\begin{tabular}{|c|c|c|c|}
\hline $\begin{array}{l}\text { Isolate } \\
\text { code* }\end{array}$ & Phylum/class** & Taxon & $\begin{array}{l}\text { Source } \\
\text { (rhizosphere) }\end{array}$ \\
\hline CSC P1 & Proteobacteria/Beta- & Burkholderia cepacia-complex & Rice \\
\hline CSC P2 & Proteobacteria/Beta- & Burkholderia cenocepacia & Rice \\
\hline CSC P3 & Firmicutes/Bacilli & Bacillus cereus-complex & Rice \\
\hline CSC P4 & Proteobacteria/Beta- & Achromobacter spanius & Rice \\
\hline CSC P5 & Firmicutes/Bacilli & Bacillus cereus-complex & Rice \\
\hline CSC P6 & Proteobacteria/Gamma- & Pseudomonas sp. & Rice \\
\hline CSC P7 & Proteobacteria/Alpha- & Azospirillum sp. & Rice \\
\hline CSC P8 & Proteobacteria/Alpha- & Azospirillum sp. & Rice \\
\hline CSC P9 & Proteobacteria/Alpha- & Rhizobium sp. & Rice \\
\hline CSC P10 & Proteobacteria/Gamma- & Azotobacter sp. & Rice \\
\hline CSC P11 & Proteobacteria/Gamma- & Azotobacter sp. & Rice \\
\hline CSC P12 & Proteobacteria/Beta- & Burkholderia anthina & Rice \\
\hline CSC N1 & Proteobacteria/Alpha- & Rbizobium sp. & Peanut \\
\hline CSC N2 & Proteobacteria/Gamma- & Pseudomonas sp. & Peanut \\
\hline CSC N3 & Proteobacteria/Alpha- & Rhizobium leguminosarum & Peanut \\
\hline CSC N7 & Proteobacteria/Alpha- & Azospirillum sp. & Peanut \\
\hline CSC N8 & Firmicutes/Bacilli & Bacillus cereus-complex & Peanut \\
\hline CSC N9 & Proteobacteria/Gamma- & Azotobactersp. & Peanut \\
\hline CSC N10 & Proteobacteria/Gamma- & Pseudomonas sp. & Peanut \\
\hline CSC N11 & Proteobacteria/Alpha- & Azospirillum sp. & Peanut \\
\hline
\end{tabular}

Notes: $*$ = A Strain with P in its code were isolated as Ca-P solubilizing bacteria, and that with $\mathrm{N}$ were isolated as nitrogen fixing bacteria ** = Alpha-,Beta- and Gamma- denote the classes Alphaproteobacteria, Betaproteobacteria and Gammaproteobacteria, respectively 
promoting rice growth were not different from that reported by Susilowati et al. (2015).

\section{Phosphate Solubilizing Ability of the Strains}

Ca-P solubilizing ability of the strains is shown in Table 3. The difference in the strength of $\mathrm{Ca}-\mathrm{P}$ solubilizing ability was not related to the taxonomic property. All strains formed halo zone around colonies, and the area ratio of the halo zone to a colony was variable (data not shown) indicating the ability to solubilize Ca-P differed among the strains. This was reflected in the Ca-P solubilizing ability which was quantitatively determined (Table 3). The highest Ca-P solubilization ability was shown by Pseudomonas sp. CSC N2 and the lowest was shown by Achromobacter spanius CSC P4. The activity of PMEase is shown in Table 3. Pseudomonas sp. CSCN2 again showed the highest PMEase activity, and Achromobacter spanius CSC P4 seemed to have no extracellular PMEase activity.

\section{Nitrogen-Fixing Ability of the Strains}

All strains belonging to Rhizobium, Azotobacter and Azospirillum genera were able to grow on nitrogen-limited media implying that these strains were able to fix nitrogen (Chien et al. 1992).

\section{IAA Production of the Strains}

IAA production of the strains is shown in Table 3. The amount of IAA produced varied depending on strains. The highest production was achieved by Azospirillum sp. CSC P8 and Azospirillum sp. CSC P7. The lowest IAA production was detected in Achromobacter spanius CSC P4.

\section{Effect of Bacterial Inoculation on the Rice}

During the 7 -day germination assay with $0.4 \%$ $\mathrm{NaCl}$, the effect of bacterial inoculation varied depending on the strains (Table 4). The best growth was obtained by the mixture of strains on INPARA-3, with $7.46 \mathrm{~cm}$ and $6.5 \mathrm{~cm}$ in shoot and root length, respectively. Medium level effect was observed in Burkholderia cepacia-complex, Bacillus cereus-complex, Pseudomonas sp., Azospirillum sp. and Azotobacter sp. However, inoculation of Burkholderia cenocepacia, Achromobacter spanius, Rhizobium sp., Burkholderia anthina and Rhizobium leguminosarum had no effect on shoot and root length. Cultivars INPARA-6 and INPARI-13 could not grow without any inoculant (control) or with five single-strain-inoculants.

In the 45-day growth assay (Table 5), the growth of rice cultivar INPARA-3 under saline

Table $3 \mathrm{Ca}_{3}\left(\mathrm{PO}_{4}\right)_{2}$ solubilization ability, PMEase activity and IAA production of the strains

\begin{tabular}{|c|c|c|c|c|}
\hline $\begin{array}{l}\text { Isolate } \\
\text { code }\end{array}$ & Taxon & $\begin{array}{l}\text { Phosphate } \\
\text { Solubilization } \\
(\mathrm{mg} / \mathrm{L})^{*}\end{array}$ & $\begin{array}{c}\text { PMEase } \\
\text { (Unit)* }\end{array}$ & $\begin{array}{c}\text { IAA } \\
\text { Production } \\
(\mathrm{mg} / \mathrm{L})^{*}\end{array}$ \\
\hline CSC P1 & Burkholderia cepacia-complex & $8.72 \pm 0.89$ & $0.63 \pm 0.71$ & $8.67 \pm 0.92$ \\
\hline CSC P2 & Burkholderia cenocepacia & $1.06 \pm 0.16$ & $0.13 \pm 0.52$ & $2.63 \pm 0.16$ \\
\hline CSC P3 & Bacillus cereus-complex & $10.54 \pm 0.16$ & $0.82 \pm 0.85$ & $8.16 \pm 0.90$ \\
\hline CSC P4 & Achromobacter spanius & $0.30 \pm 0.68$ & $0.01 \pm 0.04$ & $1.94 \pm 0.21$ \\
\hline CSC P5 & Bacillus cereus-complex & $1.51 \pm 0.11$ & $0.10 \pm 0.86$ & $5.46 \pm 0.58$ \\
\hline CSC P6 & Pseudomonas sp. & $11.26 \pm 0.58$ & $0.75 \pm 0.26$ & $8.27 \pm 0.67$ \\
\hline CSC P7 & Azospirillum sp. & $7.39 \pm 0.42$ & $0.60 \pm 0.86$ & $9.45 \pm 0.06$ \\
\hline CSC P8 & Azospirillum sp. & $6.68 \pm 0.37$ & $0.68 \pm 0.10$ & $9.56 \pm 0.16$ \\
\hline CSC P9 & Rhizobium sp. & $2.28 \pm 0.63$ & $0.51 \pm 0.70$ & $6.08 \pm 0.42$ \\
\hline CSC P10 & Azotobacter sp. & $5.71 \pm 0.53$ & $1.27 \pm 0.68$ & $8.75 \pm 0.98$ \\
\hline CSC P11 & Azotobacter sp. & $1.57 \pm 0.95$ & $0.49 \pm 0.67$ & $6.21 \pm 0.32$ \\
\hline CSC P12 & Burkholderia anthina & $0.47 \pm 0.47$ & $0.10 \pm 0.12$ & $2.13 \pm 0.16$ \\
\hline CSC N1 & Rhizobium sp. & $1.18 \pm 0.05$ & $2.01 \pm 0.34$ & $3.82 \pm 0.89$ \\
\hline CSC N2 & Psendomonas sp. & $11.39 \pm 0.53$ & $2.22 \pm 0.93$ & $8.16 \pm 0.90$ \\
\hline CSC N3 & Rhizobium leguminosarum & $4.94 \pm 0.32$ & $0.31 \pm 0.27$ & $8.61 \pm 0.10$ \\
\hline CSC N7 & Azospirillum sp. & $2.00 \pm 0.32$ & $0.47 \pm 0.03$ & $7.61 \pm 0.39$ \\
\hline CSC N8 & Bacillus cereus-complex & $0.89 \pm 0.95$ & $0.12 \pm 0.88$ & $2.73 \pm 0.68$ \\
\hline CSC N9 & Azotobacter sp. & $0.83 \pm 0.89$ & $0.45 \pm 0.09$ & $8.39 \pm 0.06$ \\
\hline CSCN10 & Pseudomonas sp. & $10.08 \pm 0.26$ & $0.85 \pm 0.89$ & $8.33 \pm 0.84$ \\
\hline CSCN11 & Azospirillum sp. & $1.86 \pm 0.47$ & $0.14 \pm 0.59$ & $8.09 \pm 0.22$ \\
\hline
\end{tabular}

Note: Values represent mean \pm standard deviation $(n=3)$ 
Table 4 The effect of bacterial inoculants on root and shoot length of rice (three cultivars) at the stage of seed germination

\begin{tabular}{|c|c|c|c|c|}
\hline Isolate code & Taxon & Rice cultivar & $\begin{array}{l}\text { Shoot length } \\
\quad(\mathrm{cm})^{*}\end{array}$ & $\begin{array}{l}\text { Root length } \\
\quad(\mathrm{cm})^{*}\end{array}$ \\
\hline Control & (Control: no inoculation) & $\begin{array}{l}\text { INPARA-3 } \\
\text { INPARI-13 } \\
\text { INPARA-6 }\end{array}$ & $\begin{array}{l}4.03 \text { a } \\
\text { dead } \\
\text { dead }\end{array}$ & $\begin{array}{l}0.51 \text { a } \\
\text { dead } \\
\text { dead }\end{array}$ \\
\hline CSC P1 & Burkbolderia cepacia-complex & $\begin{array}{l}\text { INPARA-3 } \\
\text { INPARI-13 } \\
\text { INPARA-6 }\end{array}$ & $\begin{array}{l}5.55 \mathrm{de} \\
4.23 \mathrm{ab} \\
4.37 \mathrm{ab}\end{array}$ & $\begin{array}{l}4.43 \text { ghi } \\
2,00 \text { bcde } \\
1.39 \text { abc }\end{array}$ \\
\hline CSC P2 & Burkholderia cenocepacia & $\begin{array}{l}\text { INPARA-3 } \\
\text { INPARI-13 } \\
\text { INPARA-6 }\end{array}$ & $\begin{array}{l}4.16 \mathrm{ab} \\
\text { dead } \\
\text { dead }\end{array}$ & $\begin{array}{l}1.47 \text { abcd } \\
\text { dead } \\
\text { dead }\end{array}$ \\
\hline CSC P3 & Bacillus cereus-complex & $\begin{array}{l}\text { INPARA-3 } \\
\text { INPARI-13 } \\
\text { INPARA-6 }\end{array}$ & $\begin{array}{l}5.54 \mathrm{de} \\
4.51 \mathrm{abcd} \\
4.59 \mathrm{abcd}\end{array}$ & $\begin{array}{l}4.24 \text { ghi } \\
2.99 \mathrm{defg} \\
2.04 \mathrm{bcde}\end{array}$ \\
\hline CSC P4 & Achromobacter spanius & $\begin{array}{l}\text { INPARA-3 } \\
\text { INPARI-13 } \\
\text { INPARA-6 }\end{array}$ & $\begin{array}{l}4.09 \text { a } \\
\text { dead } \\
\text { dead }\end{array}$ & $\begin{array}{l}2.90 \text { cdefg } \\
\text { dead } \\
\text { dead }\end{array}$ \\
\hline CSC P6 & Pseudomonas sp. & $\begin{array}{l}\text { INPARA-3 } \\
\text { INPARI-13 } \\
\text { INPARA-6 }\end{array}$ & $\begin{array}{l}5.58 \mathrm{de} \\
4.55 \mathrm{abcd} \\
4.79 \mathrm{abcd}\end{array}$ & $\begin{array}{l}4.70 \text { hi } \\
3.41 \text { efgh } \\
3.22 \text { efgh }\end{array}$ \\
\hline CSC P8 & Azospirillum sp. & $\begin{array}{l}\text { INPARA-3 } \\
\text { INPARI-13 } \\
\text { INPARA-6 }\end{array}$ & $\begin{array}{l}6.10 \mathrm{e} \\
4.80 \mathrm{abcd} \\
4.94 \mathrm{abcd}\end{array}$ & $\begin{array}{l}5.00 \mathrm{i} \\
3.65 \mathrm{fghi} \\
3.11 \mathrm{efgh}\end{array}$ \\
\hline CSC N1 & Rhizobium sp. & $\begin{array}{l}\text { INPARA-3 } \\
\text { INPARI-13 } \\
\text { INPARA-6 }\end{array}$ & $\begin{array}{l}4.30 \mathrm{ab} \\
\text { dead } \\
\text { dead }\end{array}$ & $\begin{array}{l}3.95 \text { fghi } \\
\text { dead } \\
\text { dead }\end{array}$ \\
\hline CSC N9 & Azotobacter sp. & $\begin{array}{l}\text { INPARA-3 } \\
\text { INPARI-13 } \\
\text { INPARA-6 }\end{array}$ & $\begin{array}{l}5.56 \mathrm{de} \\
4.82 \mathrm{abcd} \\
4.31 \mathrm{ab}\end{array}$ & $\begin{array}{l}4.44 \text { ghi } \\
2.83 \text { cdefg } \\
2.39 \text { bcdef }\end{array}$ \\
\hline CSC N12 & Burkholderia anthina & $\begin{array}{l}\text { INPARA-3 } \\
\text { INPARI-13 } \\
\text { INPARA-6 }\end{array}$ & $\begin{array}{l}4.03 \text { a } \\
\text { dead } \\
\text { dead }\end{array}$ & $\begin{array}{l}1.25 \text { ab } \\
\text { dead } \\
\text { dead }\end{array}$ \\
\hline CSC N3 & Rbizobium leguminosarum & $\begin{array}{l}\text { INPARA-3 } \\
\text { INPARI-13 } \\
\text { INPARA-6 }\end{array}$ & $\begin{array}{l}4.34 \\
\text { dead } \\
\text { dead }\end{array}$ & $\begin{array}{l}3.62 \\
\text { dead } \\
\text { dead }\end{array}$ \\
\hline Mix & Mixture of strain & $\begin{array}{l}\text { INPARA-3 } \\
\text { INPARI-13 } \\
\text { INPARA-6 }\end{array}$ & $\begin{array}{l}7.46 \mathrm{f} \\
4.98 \mathrm{abcd} \\
4.96 \mathrm{abcd}\end{array}$ & $\begin{array}{l}6.50 \mathrm{j} \\
4.01 \text { ghi } \\
4.13 \text { ghi }\end{array}$ \\
\hline
\end{tabular}

Note: Values followed by the same letter in the same column are not significantly different based on Duncan's multiple range test at $5 \%$ level

condition was less than that under no saline condition. Under saline condition, rice cultivar INPARA-3 inoculated with the mixture of strains showed the best growth with $29 \mathrm{~cm}$ in plant height and $5.5 \mathrm{~cm}$ in root length. As a single isolate inoculation, Pseudomonas sp. CSC N6 showed the best effect.

Twenty strains with Ca-P solubilizing, extracellular PMEase producing and IAA producing abilities were successfully obtained, with an exception of $A$. spanius CSC P4 that did not show clear PMEase activity. These strains did not lean to a specific taxonomic lineage and composed of members of the phyla Proteobacteria (the classes Alphaproteobacteria, Betaproteobacteria and Gammaproteobacteria) and Fermicutes. The fact that the strains were isolated as nitrogen-fixing bacteria including $\mathrm{Ca}-\mathrm{P}$ solubilizing members indicated that $\mathrm{Ca}-\mathrm{P}$ solubilizing ability was common among bacteria, at least among those living in the rhizosphere. It was also possible that PMEase activity was common among 
Table 5 The effect of bacterial inoculants on the growth of rice cultivar INPARA-3, in sterile sand media under saline and non-saline conditions 45 days after planting

\begin{tabular}{|c|c|c|c|c|c|}
\hline $\begin{array}{l}\text { Isolate } \\
\text { code }\end{array}$ & Inoculant & $\begin{array}{l}\text { Salinity } \\
\text { condition }\end{array}$ & $\begin{array}{l}\text { Total dry } \\
\text { biomass } \\
\text { (g) }\end{array}$ & $\begin{array}{l}\text { Plant } \\
\text { height } \\
(\mathrm{cm})\end{array}$ & $\begin{array}{l}\text { Root } \\
\text { length } \\
(\mathrm{cm})\end{array}$ \\
\hline \multirow[t]{2}{*}{-} & No bacteria & Non-saline & $0.02 \mathrm{a}$ & $14.25 \mathrm{ab}$ & $1.50 \mathrm{ab}$ \\
\hline & & Saline & $0.01 \mathrm{a}$ & $13.00 \mathrm{a}$ & $1.00 \mathrm{a}$ \\
\hline \multirow[t]{2}{*}{ CSC P1 } & Burkholderia cepacia-complex & Non-saline & 0.09 cde & $27.50 \mathrm{ghi}$ & $5.00 \mathrm{jk}$ \\
\hline & & Saline & $0.07 \mathrm{abcd}$ & 26.25 ghi & 4.00 hij \\
\hline \multirow{2}{*}{ CSC P2 } & Burkholderia cenocepacia & Non-saline & $0.06 \mathrm{abcd}$ & $26.00 \mathrm{fgh}$ & $3.50 \mathrm{fgh}$ \\
\hline & & Saline & $0.04 \mathrm{abc}$ & 22.75 cdefg & $2.65 \mathrm{de}$ \\
\hline \multirow[t]{2}{*}{ CSC P3 } & Bacillus cereus-complex & Non-saline & 0.09 cde & $27.30 \mathrm{ghi}$ & $4.50 \mathrm{ij}$ \\
\hline & & Saline & $0.08 \mathrm{bcd}$ & $26.00 \mathrm{fgh}$ & $3.75 \mathrm{ghi}$ \\
\hline \multirow[t]{2}{*}{ CSCP4 } & Achromobacter spanius & Non-saline & $0.04 \mathrm{abc}$ & 25.50 efgh & $3.50 \mathrm{fgh}$ \\
\hline & & Saline & $0.02 \mathrm{a}$ & $17.00 \mathrm{abc}$ & 3.00 ef \\
\hline \multirow[t]{2}{*}{ CSC P6 } & Pseudomonas sp. & Non-saline & 0.13 e & $29.50 \mathrm{hi}$ & 6.151 \\
\hline & & Saline & 0.09 cde & $26.88 \mathrm{ghi}$ & $5.00 \mathrm{jk}$ \\
\hline \multirow[t]{2}{*}{ CSC P8 } & Azospirillum sp. & Non-saline & 0.09 cde & $27.50 \mathrm{ghi}$ & $4.25 \mathrm{ij}$ \\
\hline & & Saline & $0.07 \mathrm{abcd}$ & $26.25 \mathrm{ghi}$ & $4.00 \mathrm{hij}$ \\
\hline \multirow{2}{*}{ CSC N1 } & Rhizobium sp. & Non-saline & $0.07 \mathrm{abcd}$ & 24.50 defgh & $3.25 \mathrm{fg}$ \\
\hline & & Saline & $0.04 \mathrm{abc}$ & 20.75 cde $^{\circ}$ & $2.25 \mathrm{~cd}$ \\
\hline \multirow[t]{2}{*}{ CSC N9 } & Azotobacter sp. & Non-saline & $0.08 \mathrm{bcd}$ & $26.50 \mathrm{ghi}$ & $4.50 \mathrm{ij}$ \\
\hline & & Saline & $0.07 \mathrm{abcd}$ & 26.25 ghi & 3.75 ghi \\
\hline \multirow[t]{2}{*}{ CSCN12 } & Burkholderia anthina & Non-saline & $0.06 \mathrm{abc}$ & $21.00 \mathrm{cdef}$ & $3.50 \mathrm{fgh}$ \\
\hline & & Saline & $0.02 \mathrm{a}$ & $17.15 \mathrm{abc}$ & $2.25 \mathrm{~cd}$ \\
\hline \multirow[t]{2}{*}{ CSC N3 } & Rhizobium leguminosarum & Non-saline & $0.05 \mathrm{abc}$ & 23.00 defg & $3.25 \mathrm{fg}$ \\
\hline & & Saline & $0.02 \mathrm{abc}$ & $19.00 \mathrm{bcd}$ & $2.00 \mathrm{bc}$ \\
\hline \multirow[t]{2}{*}{-} & Mixture of all the isolates & Non-saline & 0.14 e & $31.00 \mathrm{i}$ & 6.501 \\
\hline & & Saline & 0.12 de & $29.00 \mathrm{hi}$ & $5.50 \mathrm{k}$ \\
\hline
\end{tabular}

Notes: Values followed by the same letter in the same column are not significantly different by Duncan's multiple range test at $5 \%$ level. Non-saline condition $=360 \mathrm{~mL}$ freshwater in 0.5 gallon pots.

Saline condition $=360 \mathrm{~mL}$ freshwater in 0.5 gallon pots was added with $0.4 \% \mathrm{NaCl}(6 \mathrm{~g} \mathrm{NaCl})$.

rhizosphere bacteria. Interestingly, the strains with higher Ca-P solubilizing ability generally showed higher PMEase activity. IAA production was also reported as common among soil bacteria (Hasan 2002; Xin et al. 2009), which was supported by the present study.

Saline environment inhibits rice growth. This is because rice is a saline sensitive plant (Ashraf \& Harris 2004); also because the uptake of $\mathrm{Ca}_{2}{ }^{+}, \mathrm{K}^{+}$ and inorganic $\mathrm{N}$ and $\mathrm{P}$ are disrupted under high $\mathrm{Na}$ concentration (Ashraf \& Harris 2004). In addition, the salinity also affected soil enzyme activities (Siddikee et al. 2011), which could indirectly affect rice growth. The inoculation of the selected strains affected germination of rice under saline condition (Table 4). The inoculation of mixture of the strains resulted in the best rice growth. As single strain, Aqospirillum sp. CSC P8 and Pseudomonas sp. CSC P6 provided the best and the second best rice growth support, respectively. It was possible that the inoculants supported the growth of rice by supplying phosphate and IAA.
Azospirillum sp. is a potential nitrogen fixer and the mixture of the strains also includes nitrogen fixers. Therefore, it was possible that nitrogen fixed by the inoculants might also promote rice growth. Rice cultivars INPARI-13 and INPARA6 did not grow without the existence of inoculants. The present study showed that the inoculation of five strains and the mixture of strains enabled these cultivars to grow. This indicated that the inoculation not only promoted rice growth by supplying nutrient and IAA, but also enhanced rice tolerance towards salinity. It was interesting that some strains isolated from peanut rhizosphere could promote and support rice growth.

Among the rice cultivars tested in the present study, only INPARA-3 grew in saline condition without inoculation of the strains. Therefore, INPARA-3 was then subjected to rice growth assay with $0.4 \% \mathrm{NaCl}$. In this assay, the inoculation of the mixture of strains, Psendomonas sp. CSC P6 and Azospirillum sp. CSC P8 provided 
the best, the second best, and the third best rice growth support, respectively. These inoculants may be promising as biofertilizer to support rice growth in saline paddy fields.

\section{CONCLUSIONS}

Twenty strains of rhizosphere bacteria with Ca-P solubilizing ability and IAA production were successfully obtained in this study. Those bacteria mainly belonged to Burkholderia cepacia-complex, Burkholderia anthina, Burkbolderia cenocepacia, Bacillus cereus-complex, Achromobacter spanius, Azospirillum sp., Azotobacter sp., Rhizobium leguminosarum, Rhizobium sp. and Pseudomonas sp.

Potential nitrogen fixing bacteria are Azospirillum sp., Azotobacter sp., Rbizobium leguminosarum and Rhizobium sp. Most strains had PMEase activity. Some strains showed growthpromoting effect on rice under saline conditions and produced plant growth hormone. These strains could be candidates for biofertilizer for rice in saline paddy field. It is also important to consider using combination of inoculants and rice cultivars to obtain maximum result.

\section{ACKNOWLEDGEMENTS}

This work was funded by JICA-JST SATREP 2011-2016. We thank Dr Shigeto Otsuka from University of Tokyo for research guidance. We are grateful to Senlie Oktavitana, Anis Mutirani and Rinatu Siwi for their assistance in laboratory works.

\section{REFERENCES}

Aquilanti LFF, Clementi F. 2004. Comparison of different strategies for isolation and preliminary identification of Azotobacter from soil samples. Soil Biol Biochem 36(9):1475-83.

Ashraf M, Harris PJC. 2004. Potential biochemical indicators of salinity tolerance in plants. Plant Sci $166(1): 3-16$.

Balser TC, McMahon KD, Bart D, Bronson D, Coyle DR, Craig N, Flores-Mangual ML, Forshay K, Jones SE, Kent AE, Shade AL. 2006. Bridging the gap between micro and macro-scale perspectives on the role of microbial communities in global change ecology. Plant Soil 289:59-70.
Banig AE, Aly EA, Khaled AA, Amel KA. 2008. Isolation, characterization and application of bacterial population from agricultural soil at Sohag Province, Egypt. Malays J Microbiol 4(2):42-50.

Bhattacharjee R, Dey U. 2014. Biofertilizer a way towards organic agriculture a review. Afr J Microbiol Res 8(24):2332-42.

Bhattacharyya PN, Jha DK. 2012. Plant growth-promoting rhizobacteria (PGPR): Emergence in agriculture. World J Microbiol Biotechnol 28:1327-50.

Cerabolini B, Andreis DR, Ceriani RM, Pierce S, Raimondi B. 2004. Seed germination and conservation of enandgered species from the Italian Alps: Physoplexis comosa and Primula glaucescens. Biol Conserv 117(3):351-6.

Chen YP, Rekha PD, Arun AB, Shen FT, Lai WA, Young CC. 2006. Phosphate solubilizing bacteria from subtropical soil and their tricalcium phosphate solubilizing abilities. Appl Soil Ecol 34(1):33-41.

Chien CT, Maundu J, Cavaness J, Dandurand LM, Orser CS. 1992. Characterization of salt-tolerant and saltsensitive mutants of Rhizobium leguminosarum biovarviciae strain C1204b. FEMS Microbiol Lett 169(2):135-40.

Crozier A, Arruda P, Monteiro AM, Sandberg G. 1988. Analysis of indole-3-acetic acid and related indoles in culture medium from Azospirillum lipoferum and Azospirillum brasilense. Appl Environ Microbiol 54(11):2833-7.

Djufry F, Sudarsono A, Lestari MS. 2011. Tingkat toleransi beberapa galur harapan padi pada kondisi salinitas di lahan rawa pasang surut.J Agrivigor 10(2):196-207.

Gravel V, Antoun H, Tweddell RJ. 2007. Growth stimulation and fruit yield improvement of greenhouse tomato plants by inoculation with Pseudomonas putida or Trichoderma atroviride: Possible role of indole acetic acid (IAA). Soil Biol Biochem 39:1968-77.

Hasan HAH. 2002. Gibberellin and auxin-indole production by plant root-fungi and their biosynthesis under salinity-calcium interaction. Acta Microbiol Immunol Hung 49(1):105-18.

Lugtenberg B, Malfanova N, Kamilova F, Berg G. 2013. Plant growth promotion by microbes. In: Bruijn FJ de (editor). Molecular microbial ecology of the rhizosphere. Hoboken (US): Wiley-Blackwell. p.561-73.

Mubarik NR, Imas T, Wahyudi AT, Triadiati, Suharyanto, Widiastuti H. 2011.The use of acid alumunium tolerant Bradyrbiqobium japonicum formula for soybean grown on field acid soil. World Acad Sci Eng Technol 53:879-82.

Nakbanpote W, Panitlurtumpai N, Sangdee A, Sakulpone N, Sirisom P, Pimthong A. 2014. Salt tolerant and plant growth-promoting bacteria isolated from $\mathrm{Zn} / \mathrm{Cd}$ 
contaminated soil: Identification and effect on rice under saline conditions. J Plant Interact 9(1):379-87.

Nguyen C, Yan W, Tacon FL, Lapeyrie F. 1992. Genetic viability of phosphate solubilizing activity by monocaryotic and dicatyotic mycelia of the ectomycorrhyzal fungus Laccaria bicolor (Maire) PD. Orton Plant Soil 3:193-9.

Nosrati R, Owlia P, Saderi H, Rasooli I, Malboobi MA. 2014. A contribution to set a legal framework for biofertilisers phosphate solubilization characteristics of efficient nitrogen fixing soil Azotobacter strains. Iran J Microbiol 6(4):285-95.

Otsuka S, Sudiana IM, Komori A, Isobe K, Deguchi S, Nishiyama M, Senoo K. 2008. Community structure of soil bacteria in a tropical rainforest several years after fire. Microbes and Environments/JSME 23:49-56. http://doi.org/10.1264/jsme2.23.49-56.

Park J, Bolan N, Mallavarapu M, Naidu R. 2011. Isolation of phosphate solubilizing bacteria and their potential for lead immobilization in soil. J Hazard Mater 185(2-3):829-36.

Pliego C, Kamilova F, Lugtenberg B. 2011. Plant growthpromoting bacteria: Fundamentals and exploitation. In: Maheshwari DK (editor). Bacteria in agrobiology: Crop ecosystems. Heidelberg (DE): Springer-Verlag. p.295-343.

Rao S. 1994. Mikroorganisme Tanah dan Pertumbuhan Tanaman. Edisi 2. Jakarta (ID): UI Press. 353p.

Rowell DL. 1994. Soil Science: Methods and Application, Longman Scientific and Technical. Harlow, Essex (UK): Longman Group. 350p.

Salamone de IEG, Funes JM, Salvo Di LP, Escobar-Ortega JS, Auria, L. Ferrando FD, Scavino F. 2012. Inoculation of paddy rice with Azospirillum brasilense and Pseudomonas fluorescens: Impact of plant genotypes on rhizosphere microbial communities and field crop production. Appl Soil Ecol 61:196-204.

Siddikee Md A, Tipayno SC, Kim K, Chung JB, Sa T. 2011. Influence of varying degree of salinity-sodicity stress on enzyme activities and bacterial populations of coastal soils of Yellow Sea. South Korea. J Microbiol Biotechnol 21(4):341-6.

Steenhoudt O, Vanderleyden J. 2000. Azospirillum, a freeliving nitrogen-fixing bacterium closely associated with grasses: genetic, biochemical and ecological aspects. FEMS Microbiol Rev 24:487-506.

Susilowati DN, Sudiana IM, Mubarik NR, Suwanto A. 2015. Species and functional diversity of rhizobacteria of rice plant in the coastal soils of Indonesia. Indones J Agric Sci 16(1):39-50. DOI 10.2108/ijas.v16n1.2015.39-50.

Tabatabai MA, Bremner JM. 1969. Use of p-nitrophenyl phosphate for assay of soil phosphate activity. Soil Biol Biochem 1:301-7.

Vassileva M, Azcon R, Barea JM, Vassilev N. 2000. Rock phosphate solubilization by free and encapsulated cells of Yarowia lipolytica. Process Biochem 35(7):693-7.

Wijebandara DM, Iranie D, Dasog GS, Patil PL, Hebbar M. 2009. Response of rice to nutrients and biofertilizers under conventional and system of rice intensification methods of cultivation in Tungabhadra command of Karnataka. Karnataka J Agric Sci 22(4):741-50.

Xin G, Glawe D, Doty SL. 2009. Characterization of three endophytic, indole-3-acetic acid-producing yeasts occurring in Populus trees. Mycol Res 113(9):973-80.

Zaller JG. 2007. Vermicompost as a substitute for peat in potting media: Effects on germination, biomass allocation, yields and fruit quality of three tomato varieties. Sci Hort 112(2):191-9. 